\title{
The Effects of COVID-19 on Early Childhood Education and Care: Research and Resources for Children, Families, Teachers, and Teacher Educators
}

\author{
Mary Renck Jalongo ${ }^{1}$
}

Accepted: 30 April 2021 / Published online: 24 May 2021

(c) The Author(s), under exclusive licence to Springer Nature B.V. 2021

\begin{abstract}
The COVID-19 world health crisis has profound implications for the care and education of young children in homes and schools, the lives of preservice and inservice teachers, and the work of college/university faculty. This article begins by discussing the implications of a world health pandemic for education and the challenges of conducting a literature review on such a rapidly evolving topic. The next four sections categorize the COVID-19 literature into themes: (1) threats to quality of life (QoL) and wellness, (2) pressure on families and intensification of inequities, (3) changes in teaching methods and reliance on technology, and (4) restructuring of higher education and scholarship interrupted. Each of the four themes is introduced with a narrative that highlights the current context, followed by the literature review. Next is a compilation of high-quality, online resources developed by leading professional organizations to support children, families, and educators dealing with the COVID crisis. The article concludes with changes that hold the greatest potential to advance the field of early childhood education and care.
\end{abstract}

\section{Implications of a World Health Pandemic for Education}

As of April 6, 2020, officials in all 50 states of the United States issued orders for school closures through the month in response to COVID-19. As I passed by our university campus on an errand to pick up essential items, I noticed a parking lot that ordinarily would have been jammed with faculty, staff, and students frantically searching for an empty space. With the exodus of the college students and the governor's stay-at-home order in effect, our college town's population had dropped by almost half. The situation was very different from what we were seeing in the media coverage of China, Italy, or New York City. Here in our small town, a group of volunteers with masks and gloves unloaded bag after bag of nonperishable groceries and other essential items from the back of three large trucks. The bags would be distributed to people in need, no questions asked. The town was quiet, yet underneath that illusion of calm, educational programs

Mary Renck Jalongo

mjalongo@ comcast.net

1 Emerita, Indiana University of Pennsylvania, 654 College Lodge Road, Indiana, PA 15701, USA were in turmoil. All in-person class gatherings at all levels of education had ceased. Early childhood programs were in suspended animation and the Head Start building stood dark and empty. Parents with children in public schools were suddenly expected to home school. University faculty quickly converted courses to online formats, puzzled over how to provide practicum experiences, and worried about how future caregivers and teachers would meet professional standards and licensure criteria.

Education plays a particularly significant role in children and adolescents' health and well-being and has a lasting impact on their lives as adults (Hamad et al., 2018). There is little question that the global health pandemic has caused unprecedented disruption to all spheres of human life and to education worldwide (d' Orville, 2020; Zhu \& Liu, 2020). UNESCO, (2020a) estimates that 1.2 billion school children had their education put on hold due to COVID-related school closures and, between late March through April of 2020 , more than $90 \%$ of the total enrolled learners worldwide experienced nationwide school closures and were confined at home. In many ways, adapting to COVID-19 has become a huge, international social experiment that not only has caused loss of learning throughout lockdown but also can be expected to diminish educational opportunities in the long term (Jandric', 2020). 
Between March 12 and 27, 2020 a survey of educators from 89 countries identified the following priorities: ensuring academic learning for students, supporting students who lack skills for independent study, providing support for teachers (medical, mental health, professional development), revising graduation policies, ensuring integrity of the assessment process, defining new curricular priorities, and providing social services and food to students (Reimers \& Schleicher, 2020). Among the concerns identified by this same international group of educators were:

- reduced opportunities for social interaction with extended family, peers, and community members

- threats to the health and safety of students, families, and educators

- financial decisions about education and program viability

- disruptions to the continuity of learning

- limited access to social services and other forms of support for families

- negative effects on students' perception of the value of study

- drastic reductions in face-to-face teaching and instructional time

- implementation of measures to continue students' learning during school closure

- teachers' preparedness to support digital learning

- when and how to reopen schools

- reductions in class size

- mobility of students and legal status of international students

- ways to provide practica, field experiences, and apprenticeships for professionals in training (Reimers \& Schleicher, 2020)

\section{Challenges with Conducting a Literature Review on COVID-19}

Reviewing the literature on COVID-19 is, in many ways, atypical. Unlike most other topics, practically every source has been published in 2020 or 2021. Many publications about coronavirus are posted online first; that is why some quotations in this article are designated as "unpaged"-they have been edited, but not yet assigned to a print version of a publication. A second distinguishing feature of the literature about the current pandemic is that it is exceptionally multidisciplinary.

Preparation for this article required searching the COVID19 literature more expansively to include quantitative, qualitative, and mixed-methods research; policy documents from respected global and national organizations; literature reviews conducted by professionals representing diverse fields, and resources prepared by prominent professional associations. New and valuable information has increased exponentially. To illustrate, in early 2020 , a search using "COVID-19" plus "early childhood education" yielded very little, but, by mid-February of 2021, nearly 20,000 hits were produced by those search terms on Google Scholar alone. The World Organization for Early Childhood, for example, introduced their position paper with the following caveat: "COVID-19 is an emerging, rapidly evolving situation" (OMEP Executive Committee, 2020).

What follows are four themes synthesized from the literature review. Each begins with a personal narrative that puts a face on the statistics and highlights important issues in the published scholarly literature. These themes are: (1) threats to quality of life and wellness; (2) intensification of pressure on families and inequities, (3) modifications to teaching and reliance on technology, and (4) restructuring of higher education and scholarship interrupted.

\section{Theme One: Threats to Quality of Life and Human Wellness}

In late spring of 2020, the mother and father of two young children tested positive for the virus. Both parents work in the health care field; the mother is a nurse's aide at a hospital, the father works in a nursing home. Although the couple became very ill, they managed to remain at home and used telehealth video calls to their family physician to get treatment. One of their young children got cold-like symptoms, but they decided not to get her tested because she recovered quickly. Throughout this time, troubling questions surfaced for the parents. How and when did they contract the virus? Would COVID-19 compromise the health of any family members over the long term? Is it inevitable that their son will succumb to the virus, given that they are living in the same house? Did the staff members at the parents' places of employment quarantine quickly enough to avert an uptick of cases in the community? What will the parents do about home schooling expectations when they are so still so fatigued? How long can the family manage without income from either parent?

This family's situation highlights two key concepts from positive psychology that are foundational to this discussion of the short- and long-term effects of a world health pandemic: quality of life (QoL) and wellness. Quality of life (QoL) has been the focus of study in psychology since the 1980s. It attempts to answer the question, "What makes it possible, not just to survive and exist, but to thrive and flourish in life?" QoL includes physical and mental health, cognitive functioning, social support, competence in work, and positive emotions such as optimism, wisdom, resilience, and so forth (Efklides \& Moraitou, 2013)—all things that 
are important to coping with COVID-19 (Burke \& Arslan, 2020).

Likewise, contemporary concepts of wellness have broadened beyond physical health (i.e., absence of disease or injury). Wellness may be defined as "a way of life oriented toward optimal health and well-being in which mind, body, and spirit are integrated by the individual to live more fully within the human and natural community" (Myers et al., 2000, p. 252). Anderson's (2016) model, for example, categorizes wellness into five broad areas: (1) emotional, (2) social, (3) intellectual, (4) physical, and (5) spiritual. Without a doubt, QoL and wellness worldwide have been impacted by the sweeping changes that children, families, and educators were forced to make within the context of the COVID-19 crisis.

Xafis, 2020 identifies six major influences on the physical and mental health and wellbeing of individuals and groups across time and generations: (1) income and wealth, (2) employment and access to health services, (3) housing, (4) food environment, (5) education, and (6) safety. Clearly, all these things have been affected dramatically by a world pandemic and coping with it on a daily basis over an extended period of time can compromise physical and mental health. As the World Health Organization (2020) notes, "Fear, worry, and stress are normal responses to perceived or real threats, and at times when we are faced with uncertainty or the unknown. So, it is normal and understandable that people are experiencing fear in the context of the COVID-19 pandemic" (unpaged). Four types of fear that characterize experiences with COVID-19 are: (1) ravages to the body, (2) worries about significant others, (3) intolerance of uncertainty, and (4) agonizing over action/inaction (Schimmenti et al., 2020). It is important to understand that anxiety and fear are associated with grief, which is normal and expected following any significant loss or change (Fegert et al., 2020). Worldwide, human beings are not only mourning the loss of life as they knew it but also are experiencing anticipatory loss, defined as the expectation that additional, future losses will occur.

Although the COVID-19 global health crisis is unique in some ways, research on the effects of previous quarantines and pandemics-such as the 1918 influenza epidemic-suggest a lasting, negative effect on QoL and wellness (Almond $\&$ Mazumder, 2005). Another way to glimpse the effects of COVID-19 on early childhood education is to examine scholarly literature, particularly studies that have been completed in countries with more prior experience in managing the disease. A compilation from several reviews of the research literature in different fields (e.g., psychiatry, nursing, forensics) and the documents published by global organizations identified the following problems associated with pandemics, both historical and current:
- Stigmatization of infected children/families and bias against residents in areas of high infection

- Illness, hospitalization, separation, loss of loved ones and caregivers, and bereavement

- Massive re-organization of family life

- Disconnection of children from their peers at school, informal play activities, organized sports, and visits to one another's homes

- Grief and mourning that may go unrecognized and remain unresolved

- Widespread loss of employment and economic hardship leading to lost housing, further migration, increased displacement, and more family separations

- Escalation of the number of children living in extreme poverty and in food insecure households

- Inability of families to provide consistent care, safe environments, and support education at home

- Increases in the incidence of domestic violence, intimate partner violence, sexual exploitation, and online predatory behavior

- Disruptions to child protective services and delayed recognition of/intervention in rising cases of abuse and neglect

- Higher rates of fear, depression, anxiety, post-traumatic stress disorder, and suicide

- Higher pregnancy rates, poorer prenatal care, and increases in maternal and child mortality and morbidity

- Postponement of health care visits, disruptions to medical treatment, suspension of vaccination programs, and medical supply shortages

- Overconsumption of food and/or unhealthy eating, infrequent vigorous physical activity, excessive screen time, and escalating obesity

- Higher rate of school dropouts resulting in lower educational attainment and possible negative effects on lifelong earnings

- Prolonged periods of isolation that can lead to feelings of loneliness or depression

- Continued avoidance of crowds, enclosed spaces, and physical contact long after quarantine is lifted (Araújo et al., 2020; Campbell, 2020; Fegert et al. 2020; Fisher \& Wilder-Smith, 2020; Out et al., 2020; Peters et al., 2020; Rundle et al., 2020; United Nations, 2020; Usher et al., 2020; Van Lancker \& Parolin, 2020; Witt et al., 2020; Yoshikawa et al., 2020).

\section{Theme Two: Pressure on Families and Intensification of Inequities}

A young family emigrated to the United States from Myanmar several years ago. Both parents work at a Thai restaurant that was closed for months and, even after it reopened, 
indoor dining was discontinued. As a result, the mother lost her job as a waitress and the father's work as a cook was limited to weekends only. The couple was proud of the business they had started-a sushi bar on campus-but it failed when the university converted most courses to online delivery. The parents were immediately thrust into home schooling and did not always understand the elementary school teachers' instructions. Given their tenuous financial situation, the couple started working outdoors-cleaning, pulling weeds, cutting grass, and raking leaves-throughout the summer and fall. Although their children needed supervision to complete school assignments, the parents had to work to meet the family's most basic needs. They had to rely on neighbors and friends for help and lived in constant fear that they would contract the disease and transmit it to their children.

Contrast them with a young mother whose job consists of providing supplies for events and social gatherings such as weddings, banquets, and so forth. She was unemployed, but her husband's income was sufficient to sustain the household, his job remained secure, and he was working from home. Everyone in this family had access to their own technological devices, indoor spaces where they could complete their work relatively undisturbed, and a large outdoor area where the family could convene for rest and relaxation. Neither parent had to be exposed to the virus because they could order whatever they needed and pick it up or have it delivered. Although there were some supply chain disruptions, the second family did not experience any food insecurity. They also had family members who were teachers to help. For the first family, the COVID-19 pandemic has been a disaster, made manageable only by the major efforts of their friends and church; for the financially secure family, it was an inconvenience.

The COVID-19 crisis challenges the popular notion of, "We're all in the same boat." First of all, the "boats" available to weather that adversity differ dramatically. Some families are cruising in luxury yachts, others are safely harbored in well-equipped houseboats, and still others are in danger of sinking at any moment on makeshift rafts. Secondly, the nature of the "storm" itself is quite different, depending upon the family's circumstances. Where workers are concerned, first responders and health care workers are living in a tsunami, other essential workers are being buffeted about by stormy seas, and many who can continue fulfil their work duties at a distance from their places of employment have comparatively smooth sailing.

Responsibilities for keeping households disinfected, doing laundry, preparing food, and doing other household chores escalated during lockdown, particularly for women (Action Aid, 2020). A study conducted in Italy found that mothers with children in the $0-5$ age group found it especially difficult to balance the demands of home and work (Del Boca et al., 2020). Parents and families have been thrust into the role of teacher under some of the worst conditions. If the family is home to more than one child, home schooling responsibilities multiply quickly because every day, Monday through Friday, new assignments related to each subject area from various teachers representing different programs keep coming in. Family members often have little or no training in supporting young children's learning and few resources, but even these limitations are not the hardest part. The most daunting task, according to a study conducted in Italy with parents whose children were on the autism spectrum, is motivating children to learn and to complete assigned tasks (Degli Espinosa et al., 2020). Even the things that could be used as rewards for children were suddenly off limits, such as playing with friends or going on an outing. Thus, parents during lockdown described having difficulties with balancing responsibilities, motivating their children, accessing online materials, and producing satisfactory learning outcomes (Garbe et al., 2020; Waddoups et al., 2019). To further compound learning losses, many young children have been deprived of a year or more of regular interactions with groups of peers that promote social and emotional development.

All the COVID-related challenges are exacerbated among the vulnerable (Ambrose, 2020), defined as "those individuals and groups routinely disadvantaged by the social injustice created by the misdistribution of power, money, and resources" (Xafis, 2020, p. 224). They include, but are not limited to indigenous peoples, those living in poverty, residents of rural/remote communities; those experiencing job and housing insecurity; people experiencing chronic mental illness, disabilities, or dependence on substances; prisoners; newly arrived migrants; refugees as well as displaced populations, stateless people, and migrant workers (Xafis et al., 2020). The suspension of childcare services due to isolation measures exacted the highest toll on families who were already struggling, and these families are most likely to experience severe, long-term deleterious effects.

Even the steps taken to protect the family-such as frequent hand washing, maintaining physical distance, and wearing personal protective equipment-were out of reach for some. Such issues were not limited to countries that lack an infrastructure for water, energy, finances, and health and education services. Wealthy countries, such as the United States, are home to young children living in extreme vulnerability, including those who are hungry, neglected, and abused. Many of the services that these children depended upon, such as healthful meals, social services, and educational interventions came to a halt with quarantine, lockdown, and physical distancing measures. Sadly, for children living in extreme adversity, early childhood programs frequently were their only respite and children lost their safe havens. Even among children whose basic needs are routinely met, educational vulnerability persists: "Preschool 
and children in early primary grades are most vulnerable as they often do not respond to online learning and are at a critical time of social, cognitive, and intellectual development" (Silverman et al., 2020, p. 463). Not all parents accepted the switch to online learning; a study in China found that parents resisted or even rejected it because they felt it was ineffective, that their young children were not sufficiently independent as learners to benefit from it, and that the parents themselves had neither the time nor expertise to accept a teaching role (Dong et al., 2020). Social-emotional vulnerability is another concern for young children. Early childhood is a critical period for learning how to deal with powerful emotions and to build skills that support positive interactions with others.

Vulnerable too are the childcare workers, who are underpaid, without health insurance, have no paid leave, became unemployed during the shutdown, and may see the programs that they worked for close, particularly if those programs depended on tuition support from families for their existence (Ali et al., 2020).

\section{Theme 3: Modifications to Teaching and Reliance on Technology}

A graduate level course was converted to online Zoom meetings during the lockdown. After several class meetings, one student asked another gently, "Could I ask you a question? You don't have to answer if you don't want to. Why are you in the garage with your phone when we meet online for class?" The student smiled and replied, "No problem-that is easy to answer. Our internet service in this rural area is not that great. The garage gets the best reception. Besides, I have younger siblings who are doing home schooling and they are using the desktop computer. They are a big distraction!

Online learning experiences generally are defined as those that rely on the internet and different digital devices (e.g., laptops, smartphones) conducted in either a synchronous or asynchronous fashion. When people blithely suggest that "everything is online now", this does not acknowledge those without such resources. The fundamental requirement of online teaching — reliable internet access and hardwaremay not be within reach for many families, even in a wealthy country such as the United States (Devine et al., 2020; Fishbane \& Tomer, 2020). A Pew Research Center report estimated that five million children and nearly one-third (31.4\%) of families with children ages 6-17 with family incomes below $\$ 50,000$ do not have a high-speed internet; this group represents about $40 \%$ of all families with school-age children in the United States (Horrigan, 2015). Further challenges to online learning include poor internet access, home environments unconducive to online learning, student difficulties with self-discipline and self-directed learning, lack of professional development for faculty, absence of holistic quality assurance systems, and means of supporting not only students' academic learning outcomes, but also their social and emotional development (Zhu \& Liu, 2020). Thrust into emergency remote teaching, a survey of K-12 educators indicated that they struggled to find high-quality tools, locate curated content aligned with standards and curriculum, use digital tools effectively, communicate with students at a distance, support student engagement/persistence, and adapt teaching material to the conditions and needs of particular students (Rasmitadila et al., 2020; Trust \& Whalen, 2020). Unprecedented long-term closure of schools and suspension of face-to-face teaching during the COVID-19 crisis surely has reduced opportunities to learn for students, particularly those of young children. In terms of social-emotional development, most children have lost the equivalent of a year or more of interaction with peers in group settings.

The young child's particular need to be actively involved and the fact that many of them are not yet reading, writing, or adept at computer keyboards makes them the least wellsuited for online approaches. Interestingly, when articles were submitted for this Special Issue, some authors denied that they were in a philosophy/reality conflict. Instead, they argued that they had managed to keep developmentally appropriate practices, principles of social learning theory, and the Reggio Emilia approach intact. Such assertions ring hollow when one considers that everything on that list is rooted in child-initiated/child-directed activity, play-based/ hands-on learning, and dynamic interpersonal interactions with peers and teachers. In a case study of young children in the South Pacific region during COVID-19, one young child poignantly captured the difference between online and inperson teaching by asking, "When are we going to have the real school?" (Dayal \& Tiko, 2020). COVID-19 has changed early childhood education at every level, from infant care to post-doctoral study.

\section{Theme 4: Restructuring of Higher Education and Scholarship Interrupted}

A new assistant professor of early childhood education is waiting to find out if she has lost her job at the university. She is a single mother whose daughter has special needs and they relocated to the area the previous year. If she is unemployed, she also has no health insurance-in the middle of a global health crisis. Prior to COVID-19, her employer's financial situation was precarious due to declining undergraduate enrollment. Now that the institution was forced to make prorated refunds of tuition, room, and board to residential students, things have spun out of control. All of the faculty members in the Department feel threatened because programs are being discontinued and departments are being 
merged or even eliminated. The administration suggests that one way to "save" a new colleague from unemployment is for the most senior professors to submit their retirement letters. Within the Department, there have been many stressful online meetings about how to schedule and staff the courses that students need to graduate, provide practicum experiences, and meet certification/licensure requirements. Throughout this upheaval, the instructor is contacted frequently by her students. They are understandably worried that they will not be adequately prepared to teach and that jobs will not be waiting for them upon graduation.

There is little doubt that COVID-19 has resulted in drastic changes to Academia. Lockdowns forced higher education to implement distance education almost overnight (Carillo \& Flores, 2020), a situation commonly referred to as "flying the airplane while we are building it". The switch to digital communication also made faculty available to students across time zones, blurring the lines between work and family. It was assumed that all faculty members could broadcast from their residence and maintain a professional presence, including parents who now had responsibility for home schooling. In a study of 1148 academics in the United Kingdom, the researchers noted that college/university faculty have been "thrust headlong into providing for their students exclusively via a digital interface" and, for many, "this has been an unusual, disorienting, and even unwelcome experience" (Watermeyer et al., 2020, unpaged). A new instructor and doctoral student, Benjamin Green, observed: "So I am now confronted with the task of undoing all of my prejudices and biases against the digital pedagogical revolution, hoping, praying that I can evolve quickly enough to provide my students with an educational experience that overcomes the obstacles present within an education system grappling against a semi-apocalyptic viral pandemic" (Peters et al., 2020, unpaged). College-level instructors also had to form partnerships with instructional technology colleagues during a time when everyone was scrambling to salvage the semester and figure out ways to engage their students from a distance (Bloom et al., 2020). Instructors without training in online course design resorted to whatever was available and familiar, such as TED Talks, YouTube videos, and massive online open courses (MOOCs). Some wrote and published about their efforts, such as Grissom (2020) who described using the professionally produced Colorin 'Colorado videos of teachers of English to simulate a classroom observation and model reflective practice.

Yet digital solutions were not without their drawbacks, and some of them related to security issues (Szente, 2020). Some hackers crashed online class meetings, awkward images were broadcast, and confidential materials became public. To avoid panic, faculty downplayed the disruptions and pressed on. Methods of assessment were shaken to their core as professors struggled to maintain the integrity of the evaluation process on tests, projects, and papers. Institutions with better infrastructures for online learning had an obvious advantage, as did the tech-savvy faculty members, who navigated the transition more easily; however, neither covering content nor evaluating written work was the hardest part.

The most formidable problem was providing practical work experience and internships (Kidd \& Murray, 2020; Marinoni, et al., 2020). Simulations had various limitations, field placements were unavailable, and opportunities to observe early childhood educators teaching, limited. Some instructors encouraged their students to make their own local arrangements to observe or interview young children. In instances where a student was struggling, the situation was even more acute. The numerous, direct observations gathered during student teaching that were necessary to justify the hard decision not to recommend certification were not available.

Internationally, mental health problems account for about one-third of the world's disability among adults and these issues escalate during deadly disease outbreaks (Otu et al., 2020). Even before the pandemic, there was a mental health crisis in college students (American College Health Association, 2018; Shackle, 2019). Forced isolation compounded students' problems because, "The university experience would fundamentally alter for many students, especially undergraduates who would no longer experience a unique life-stage of social learning and development and lead to the abandonment of higher education as a socially immersive and participatory learning experience" (Watermeyer et al., 2020). For many students, worries about health and safety made it difficult to concentrate on studies, academic enthusiasm waned, and faint hopes of future employment undermined persistence at program completion.

During COVID-19 lockdowns and quarantines throughout the world, the mental health issues of adolescents and college students surfaced or were exacerbated (Aristovnik et al., 2020; Gritsenk et al., 2020). Among international students, the circumstances frequently were even worse (Stewart et al., 2021). Travel bans were instituted, campus housing faced shutdowns, finances depleted, and visa restrictions became problematic. International students had traveled great distances expecting to be immersed in a new culture and hoping to develop greater proficiency in another language, only to find themselves isolated and working from a computer. In a qualitative study of faculty and students involved in international university programs, they used the words "painful", "heartbroken", and "crestfallen" to describe their experiences during the COVID-19 lockdown (Peters et al., 2020).

As student support services were curtailed or even discontinued, faculty members were available $24 / 7$ through digital means and were contacted frequently by needy, stressed, anxious, fearful, and panic-stricken students. Professors had 
concerns about "assuming levels of responsibility for students' welfare that often exceeded their expertise and training, what might be reasonably asked of them, and moreover their contractual and thus legal obligations" (Watermeyer et al., 2020). Nevertheless, respondents in a study of 30,383 students from 62 countries during the first wave of COVID19 crisis in early 2020 rated faculty members as the most satisfactory source of support (Aristovnik et al., 2020).

The need to provide more support to family members, restructure course delivery, revise policies/programs/planning, attend to students' needs, and support distressed colleagues. "Zoom fatigue" was such a pervasive phenomenon that National Geographic published an article explaining why the online meetings were so dissatisfying (Sklar, 2020). They failed to provide what only face-to-face events can offer: "the electricity of real-time idea exchange, the expansion of possibilities that come with open debate, the connectivity of human warmth and emotion" (Bloom et al., 2020).

Scholarly work has suffered too-so much so that some institutions gave faculty another year to work toward tenure. Researchers saw their plans for data collection and analysis postponed or even abandoned, and some of their support personnel, such as graduate assistants, were unavailable. Finding the time and place to complete scholarly work was another hurdle (Cutri et al., 2020) as home offices were repurposed into online college classrooms or became places to home school children. Professional organizations with annual conferences as a major source of revenue were forced to cancel these important events in the lives of scholars. The networking and collaborative projects that often are initiated at these gatherings were greatly diminished and some scholarly publishers, already operating on slim profit margins, faltered and failed.

Human beings have been battered and beaten in so many ways by this highly transmittable and health-jeopardizing virus. Think about the terminology that is in use throughout the world to describe our current situation: disaster, pandemic, global health crisis, national emergency, lockdown, quarantine, stay-at-home order, and Draconian measures. There is little question that the steps taken internationally to halt the spread of COVID-19 have exacted a heavy toll on our lives. Despite the overwhelming negativity, hope remains because "times of crisis and disruption offer opportunities for resilience, growth and extraordinary development" (Witt et al., 2020, p. 3).

\section{On the Other Side of the Pandemic}

Indian novelist/activist Arundhati Roy (2020) suggests a more positive metaphor for the COVID-19 crisis; that of a portal. It is a pathway that leads to a reconfigured future and we stand on a threshold leading to that journey. What possible good might come from managing to prevail in the time of coronavirus?

\section{Promotion of Ethical Practices/Policies, Global Perspectives, and Collaborative Scholarship}

The COVID-19 situation is the consummate unstructured problem that confounds efforts to solve it in a linear, stepwise fashion. Effective responses thus far have highlighted the survival skill set of the future, namely: global perspectives, multidisciplinary collaboration, innovative thinking, and principled practice. If only the global community will heed it, there are important lessons to take away from the COVID-19 experience. "The pandemic has exposed how reliant we all are on each other, how the health of the disadvantaged impacts on the advantaged, how events in one country impact on lives in others, how economies are impacted by the health of the people whose labor they rely on and on the health of those excluded from the labor market, and how we can only fight some battles united" (Xafis, 2020 , p. 225). In many ways, the situation of COVID-19 has created a "perfect moral storm" (Xafis et al., 2020) that will rely on an "ethos of community" to move forward (Green, 2020). Worldwide, people and organizations collaborated to create helpful resources. Table 1 includes many prime examples of international, interagency collaborations and datainformed recommendations that educators can put to use in helping families, students, co-workers, and themselves.

\section{Re-examination of the Concept of Childhood}

Sara Lawrence Lightfoot (1978) coined the word childism to refer to the mistaken assumption that children's emotions do not run as deep as those of adults and that children can be expected to recover more readily from adversity than mature individuals. This adult-centric view tends to minimize the effects of change and crisis on young children, assumes that they are oblivious to bad situations, and expects them to be exceptionally resilient. For some families, COVID-19 quarantine resulted in parents spending significantly more time in the company of their children and witnessing, firsthand, worrisome changes in behavior (Evans et al. 2020; Waddoups et al., 2019). Families could see for themselves that young children are at the epicenter of the disaster as support networks fell away. Perhaps the COVID crisis will help the general population to abandon childism, recognize that children's social and emotional development are just as important as their schoolwork, and acknowledge that inherent vulnerability of the youngest human beings. 
Table 1 Recommended Online Resources about COVID-19 for Children, Families, and Educators

American Academy of Child and Adolescent Psychiatry

Offers a downloadable coronavirus resource library with sections for parents and children. For example, Talking to Children about Coronavirus is writ-

ten by a child psychiatrist, to help adults discuss the pandemic and respond to children's questions

https://www.acap.org/coronavirus

American Psychiatric Association

An information hub, including hotlines accessed via telephone or text, APA publications, and publications by other mental health organizations. The

APA Center for Workplace Mental Health has several helpful resources, including: Employee Mental Health \& Well-being During \& Beyond COVID-

19, Coronavirus and Mental Health: Taking Care of Ourselves During Infectious Disease Outbreaks, and Working Remotely During COVID-19: Your

Mental Health and Well-being

https://www.psychiatry.org/psychiatrists/covid-19-coronavirus?utm_source=Internal-Link\&utm_medium=Side-Hero\&utm_campaign=Covid-19

Anna Freud National Centre for Children and Families: Coronavirus Support

This site has helpful resources in the following categories: young people, parents and carers, schools and colleges, early years, and mental health workers

https://www.annafreud.org/what-we-do/anna-freud-learning-network/coronavirus/

Association for Psychological Science (2020)

Human behavior in the time of COVID-19: Learning from psychological science

Offers straightforward advice on coping with loneliness, stress, anxiety and depression when living through quarantine and pandemics

https://www.psychologicalscience.org/observer/human-behavior-in-the-time-of-covid-19

Center for the Study of Traumatic Stress

A hub of resources for families and leaders in English, Spanish, and French. Some of their Fact Sheets on COVID include: Supporting Homebound

Children During COVID-19, Finding the Right Words to Talk with Children and Teens about Coronavirus, Discussing Coronavirus with your Chil-

dren, Tips for Coping when Quarantined with COVID-19 Family Members, and When Family Members are Hospitalized due to COVID-19. They also

have infographics. Educators are invited to submit their concerns to: listeningtoeducators@ cstsonline.org

https://www.cstsonline.org/resources/resource-master-list/coronavirus-and-emerging-infectious-disease-outbreaks-response

Children's Television Workshop

The Sesame Street Family Town Hall about COVID-19 with CNN is a clear, developmentally appropriate explanation of what children can do to stay

safe and help during the pandemic, complete with the Muppets

https://video.search.yahoo.com/yhs/search?fr=yhs-symantec-ext_onb\&hsimp=yhs-

Coronavirus: A Book for Children

A free, downloadable picture book designed for children ages 5 to 9 . It was developed with input from a professor of infectious disease modeling, a

child psychologist, teachers, and the illustrator of the popular children's book, The Gruffalo, Axel Scheffler. The book answers the questions: What is

the coronavirus? How do you catch the coronavirus? What happens if you catch the coronavirus? Why are people worried about catching the corona-

virus? Is there a cure for the coronavirus? Why are some places we normally go to closed? What can I do to help? and

What's going to happen next?

https://nosycrowcoronavirus.s3-eu-west-1.amazonaws.com/Coronavirus+-+A+book+for+children+about+Covid-19.pdf

COVID Health Literacy Project

A wide array of fact sheets, produced by physicians and in collaboration with Harvard Health Publishers. Many of resources are available already trans-

lated into 40 different languages. Of particular interest to early childhood educators is the COVID Fact Sheet for 3-to 6-year-olds that is a full color,

illustrated poster. It concludes with a message for parents and caregivers posted at:

English Children 3-6 FINAL.pdf-Google Drive

https://covid19healthliteracyproject.com/\#

Global Educational Innovation Initiative, Harvard University

Teachers will find that this extensive, annotated guide to curriculum, professional development resources, and online teaching tools is helpful and well

organized. It also is likely to include some resources that are new to them. Many of the resources are published in different languages. The download-

able, free pdf Supporting the Continuation of Teaching and Learning during the COVID-19 Pandemic is a collaborative project with representation

from several different leading professional organizations published by Organization for Economic Cooperation and Development (OECD)

https://globaled.gse.harvard.edu/files/geii/files/supporting-the-continuation-of-teaching-and-learning-during-the-covid-19-pandemic.pdf

Interagency Standing Committee

My Hero Is You: Story Book for Children on COVID 19

Many leading organizations-including the World Health Organization, the United Nations Children's Fund and Save the Children-collaborated to

produce a picture book that explains COVID-19 to children (suggested age range is 6-11). It raises and answers many concerns and questions that

children have. The book is available in over 100 different languages, including Braille

https://interagencystandingcommittee.org/iasc-reference-group-mental-health-and-psychosocial-support-emergency-settings/my-hero-you

International Association for Child and Adolescent Psychiatry and Allied Professions (IACAPAP)

This site contains numerous resources available in many different languages. In REMEMBER: How to Survive the Pandemic with Your Children! a Harvard professor and psychiatrist at Boston Children's Hospital highlights seven strategies to support those responsible for children during the pandemic. Concise and in color, the page is suitable for sharing

https://iacapap.org/remember-surviving-the-pandemic-with-your-children/

Another publication is Tips for Parents in Confinement Situations. It is a

color poster of strategies, suitable for sharing with families

https://iacapap.org/tips-for-parents-in-confinement-situations/

The Lancet Child \& Adolescent Health

Their statement, Protecting the Psychological Health of Childrenthrough Effective Communication about COVID-19 (Dalton, Rapa and Stein 2020)

provides guidelines based on empirical research

Protecting the psychological health of children through effective communication about COVID-19-The Lancet Child \& Adolescent Health

MindEd Resilience Hub (UK)

The Royal College of Psychiatrists and Health Education England have partnered to produce key resources about COVID-19, including the categories

of: Helping Each Other, Stress \& Fear, Tips for Leaders and Managers, Trauma \& Loss, and End of Life and Bereavement

http://covid.minded.org.uk

National Child Traumatic Stress Network

This site is repository of fact sheets. One that university faculty will want to read is Coping in Hard Times: Fact Sheet for Youth High School and Col-

lege Age. Many times, educators worry about saying the wrong thing, so Fighting the Big Virus: Trinka's and Sam's Questions https://www.nctsn.org/

resources/fighting-the-big-virus-trinka-and-sam-questions 0 also available in Spanish, is helpful. The site also includes resources on trauma-informed 


\section{Renewed Resolve to Address the Global Child Care Crisis}

In a working paper written for The United Nations, the authors argued that the world was already in a global childcare crisis prior to the pandemic because high-quality childcare was out-of-reach for many families around the globe (Gromada et al., 2020). Early childhood education and care is essential work. Dealing with home schooling made it evident that teachers and caregivers of young children have to do more than meet basic needs, provide structure and routine, and offer learning activities. Families soon realized that those things are easy compared to motivating children to learn and to complete assigned tasks. A mother from a wealthy community said, airily, "Oh, we are doing learning pods here-are you doing pods where you live?" She was referring to the practice of designating a small group of children who have tested COVID-19 negative to gather together for homeschooling while continuing to practice the measures to control the spread of the disease (Herzog \& Eastman, 2020). Parents, usually mothers, take turns leading the group. The presumed advantages are shared responsibility for childcare and provision of opportunities for children to interact with peers. A key point here is that a trustworthy adult has to be available to supervise, so pods are far from a solution for many families. Responsibility for advancing the learning of young children is not for amateurs; it requires professional knowledge, skill, and patience. Learning pods pale in comparison to the huge investments that are necessary, such as the following long-term structural reforms to early childhood education recommended in a report published in Australia:

- Develop a resilient, secure, and sustainable early childhood education and care system

- Build schools' and teachers' capacity to continue teaching and learning online and via other flexible modes of delivery to better manage future disruptions

- Focus more on student-centered learning and development of general capabilities, including resilience, creativity and problem-solving. These capabilities should be treated with the same importance as foundational skills such as literacy and numeracy.

- Address persistent inequality in schools and address disparities in relation to funding, instructional resources and physical infrastructures (Noble et al., 2020)

Ideally, adapting to the world health crisis would encourage more educators at all levels to shift from "traditional, teacher-centered, and lecture-based activities toward more student-centered activities including group activities, discussions, hands-on learning activities, and limited use of traditional lectures", leading to "a more sustainable, inclusive, and equitable education after the pandemic is gone" (Zhu \& Liu, 2020).

\section{Conclusion}

One reason that COVID-19 has riveted global attention is that, this time, those with more social capital have had their lives disrupted. For example, the Ebola virus had horrific symptoms, very young children were the most vulnerable group, and the disease was more likely to be fatal than COVID, but it was concentrated in West Africa and a vaccine was developed comparatively quickly (National Institute of Allergy \& Infectious Diseases, 2019). Appalling as Ebola was, it did not affect huge numbers of people worldwide as COVID has. The current pandemic has exposed the inadequacy of our systems and responses. "The pandemic's disproportionate, tragic consequences for health and livelihoods-for individuals, their communities, and even whole societies - underscore institutionalized forms of discrimination rooted in race, ethnicity, class, gender, sexual orientation, age, and abilities" (Arnove, 2020, unpaged). Even as vaccinations are being rolled out, it is obvious that there are "haves" and "have nots" and practices/policies that that serve to perpetuate bias and exclusion. Grappling with COVID-19 has made it clear that mental and physical health are indivisible. Ideally, in the aftermath of the pandemic, societies worldwide will begin working toward linking mental and physical health support services, particularly for marginalized and vulnerable groups.

It is encouraging to witness leading experts from various disciplines - such as The WHO-UNICEF-Lancet Commissioners, 2020-joining forces to argue more cogently for high-quality educational experiences that commence at the very beginning of children's lives. Three powerful ideas that bind the field of early childhood education and care together need to become part of the international educational landscape. They are: (1) early childhood represents an irreplaceable opportunity for growth, development and learning; (2) the experiences of young children are formative and exert an influence across the lifespan; and (3) taking positive action during the early years can prevent more serious issues later on. The fervent hope is that COVID-19 provides a rare opportunity to create a stronger, more equitable and humanitarian society (Davidai et al., 2020). The world needs to move beyond vague assertions that about young children's rights and political rhetoric about children representing our future. Instead, the global community needs to demonstrate-through major financial commitments and enlightened policies and practices — that the care and education of the very young is an international priority. 


\section{References}

ActionAid. (2020). Five ways the-COVID-19 pandemic impacts women worldwide. https://actionaid.org.au/5-ways-the-COVID-19-pande mic-impacts-women-worldwide-2/

Ali, U., Herbst, C. M., \& Makridis, C. A. (2021). The impact of COVID-19 on the U. S. child care market: Evidence from stayathome orders. Economics of Education Review, 82, https://doi.org/ $10.2139 /$ ssrn.3600532.

Aliyyah, R. R., Rachmadtullah, R., Samsudin, A., Syaodih, E., Nurtanto, M., \& Tambunan, A. R. S. (2020). The perceptions of primary school teachers of online learning during the COVID-19 pandemic period: A case study in Indonesia. Journal of Ethnic and Cultural Studies, 7(2), 90-109. https://doi.org/10.29333/ ejecs $/ 388$

Almond, D., \& Mazumder, B. (2005). The 1918 influenza pandemic and subsequent health outcomes: An analysis of SIPP data. American Economic Review, 95(2), 258-262. https://doi.org/10.1257/ 000282805774669943

Ambrose, A. J. H. (2020). Inequities during COVID-19. Pediatrics, 146(2), e20201501. https://doi.org/10.1542/peds.2020-1501

American College Health Association. (2018). American College Health Association-National College Health Assessment II: Reference Group Executive Summary Spring 2018. https://www.acha. org/documents/ncha/NCHAII_Spring_2018_Reference_Group_ Executive_Summary.pdf

Anderson, D. S. (Ed.). (2016). Wellness issues for higher education: A guide for student affairs and higher education professionals. Routledge.

Araújo, L. A., Veloso, C. F., Souza, M. C., Azevedo, J. M., \& Tarro, G. (2020). The potential impact of the COVID-19 pandemic on child growth and development: A systematic review. Jornal De Pediatria. https://doi.org/10.1016/j.jped.2020.08.008

Aristovnik, A., Keržič, D., Ravšelj, D., Tomaževič, N., \& Umek, L. (2020). Impacts of the COVID-19 pandemic on life of higher education students: A global perspective. Sustainability, 12(2), 8438. https://doi.org/10.3390/su12208438

Arnove, R. F. (2020). Imagining what education can be postCOVID-19. Prospects, 49, 43-46. https://doi.org/10.1007/s11125020-09474-1.pdf

Bloom, D. A., Reid, J. R., \& Cassady, C. I. (2020). Education in the time of COVID-19. Pediatric Radiology, 12(20), 8438. https:// doi.org/10.1007/s00247-020-04728-8

Burke, J., \& Arslan, G. (2020). Positive education and school psychology during COVID-19 pandemic. Journal of Positive School Psychology, 4(2), 137-139. https://doi.org/10.47602/jpsp.v4i2.243

Campbell, A. M. (2020). An increasing risk of family violence during the COVID-19 pandemic: Strengthening community collaborations to save lives. Forensic Science International Reports. https:// doi.org/10.1016/j.fsir.2020.100089

Carrillo, C., \& Flores, M. A. (2020). COVID-19 and teacher education: A literature review of online teaching and learning practices. European Journal of Teacher Education, 43(4), 466-487. https:// doi.org/10.1080/02619768.2020.1821184

Cutri, R. M., Mena, J., \& Whiting, E. F. (2020). Faculty readiness for online crisis teaching: transitioning to online teaching during the COVID-19 pandemic. European Journal of Teacher Education, 43(4), 523-541. https://doi.org/10.1080/02619768.2020.1815702

d'Orville, H. (2020). COVID-19 causes unprecedented educational disruption: Is there a road towards a new normal? Prospects, 49 , $11-15$.

Davidai, S., Day, M. V., Goya-Tocchetto, D., Hauser, O. P., Jachimowicz, J., Mirza, M., \& Tepper, S. J. (2020, April 27). COVID-19 Provides a rare opportunity to create a stronger, more equitable society. https://doi.org/10.31234/osf.io/hz4c7
Dayal, H. C., \& Tiko, L. (2020). When are we going to have the real school? A case study of early childhood education and care teachers' experiences surrounding education during the COVID19 pandemic. Australasian Journal of Early Childhood, 45(4), 336-347. https://doi.org/10.1177/1836939120966085

Degli Espinosa, F., Metko, A., Raimondi, M., Impenna, M., \& Scognamiglio, E. (2020). A model of support for families of children with autism living in the Covid-19 lockdown: lessons from Italy. Behavioral Analysis and Practice, 13(3), 1-9. https://doi. org/10.1007/s40617-020-00438-7

Del Boca, D., Oggero, N., Profeta, P., \& Rossi, M. (2020). Women's and men's work, housework and childcare, before and during COVID-19. Review of Economics of the Household, 18, 10011017. https://doi.org/10.1007/s11150-020-09502-1

Devine, N., Stewart, G., \& Benade, L. (2020). Access denied: Academic life under lockdown. New Zealand Journal of Educational Studies. https://doi.org/10.1007/s40841-020-00170-4

Dong, C., Cao, S., \& Li, H. (2020). Young children's online learning during COVID-19 pandemic: Chinese parents' beliefs and attitudes. Children and Youth Services Review. https://doi.org/10. 1016/j.childyouth.2020.105440

Efklides, A., \& Moraitou, D. (Eds.). (2013). A positive psychology perspective on quality of life. Springer.

Evans, S., Mikocka-Walus, A., Klas, A., Olive, L., Sciberras, E., Karantzas, G., \& Westrupp, E. M. (2020). From "it has stopped our lives" to "spending more time together has strengthened bonds": The varied experiences of Australian families during COVID-19. Frontiers in Psychology, 11, 588667. https://doi.org/ 10.3389/fpsyg.2020.58866

Fegert, J. M., Vitiello, B., Plener, P. L., \& Clemens, V. (2020). Challenges and burden of the Coronavirus 2019 (COVID-19) pandemic for child and adolescent mental health: A narrative review to highlight clinical and research needs in the acute phase and the long return to normality. Child Adolescent Psychiatry and Mental Health. https://doi.org/10.1186/s13034-020-00329-3

Fishbane, L., \& Tomer A. (2020). As classes move online during COVID-19, what are disconnected students to do? www.brook ings.edu/blog/the-avenue/2020/03/20/as-classes-move-online-during-covid-19-what-are-disconnected-students-to-do/

Fisher, D., \& Wilder-Smith, A. (2020). The global community needs to swiftly ramp up the response to contain COVID-19. Lancet. https://doi.org/10.1016/S0140-6736(20)30679-6

Garbe, A., Ogurlu, U., Logan, N., \& Cook, P. (2020). Parents' experiences with remote education during COVID-19 school closures. American Journal of Qualitative Research, 4(3), 45-65. https:// doi.org/10.29333/ajqr/8471

Green, B. (2020). In pursuit of an 'ethos of community': Postdigital education in the age of COVID-19. Postdigital Science and Education, 2, 681-689. https://doi.org/10.1007/s42438-020-00123-6

Grissom, D. (2020). Experiential learning through video observations. In R. E. Ferdig, E. Baumgartner, R. Hartshorne, R. KaplanRakowski \& C. Mouza (Eds). Teaching, technology, and teacher education during the COVID-19 pandemic: Stories from the field. (pp. 97-112). Waynesville, NC: Association for the Advancement of Computing in Education (AACE). https://www.learntechlib. org/p/216903/

Gritsenko, V., Skugarevsky, O., Konstantinov, V., Khamenka, N., Marinova, T., Reznik, A., \& Isralowitz, R. (2020). COVID 19 fear, stress, anxiety, and substance use among Russian and Belarusian university students. International Journal of Mental Health and Addiction. https://doi.org/10.1007/s11469-020-00330-z

Gromada, A., Richardson, D., \& Rees, G. (2020). Childcare in a global crisis: The impact of COVID-19 on work and family life. United Nations. https://doi.org/10.18356/16d757a1-en

Hamad, R., Elser, H., Tran, D. C., Rehkopf, D. H., \& Goodman, S. N. (2018). How and why studies disagree about the effects of 
education on health: A systematic review and meta-analysis of studies of compulsory schooling laws. Social Science \& Medicine, 212, 168-178. https://doi.org/10.1016/j.socscimed.2018.07.016

Herzog, N., \& Eastman, K. (2020, September 6). Are learning pods safe for your children? https://www.cedars-sinai.org/newsroom/ covid-19-are-learning-pods-safe-for-your-children/

Horrigan, J. B. (2015, April 20). The numbers behind the broadband "homework gap." Pew Research Center: Fact tank news in the numbers. http://pewrsr.ch/1IxSAJ2

Jandrić, P. (2020). Editorial: Post-digital research in the time of COVID-19. Postdigital Science and Education, 2, 233-238. https://doi.org/10.1007/s42438-020-00113-8

Kidd, W., \& Murray, J. (2020). The Covid-19 pandemic and its effects on teacher education in England: How teacher educators moved practicum learning online. European Journal of Teacher Education, 43(4), 542-558. https://doi.org/10.1080/02619768.2020. 1820480

Lightfoot, S. L. (1978). Worlds apart: Relationships between families and schools. Basic Books.

Marinoni, G., Van't Land, H., \& Jensen, T. (2020). The impact of Covid-19 on higher education around the world: IAU global survey report. Paris: International Association of Universities. https:// www.iau-aiu.net/IMG/pdf/iau_covid19_and_he_survey_report_ final_may_2020.pdf

Myers, J. E., Sweeney, T. J., \& Witmer, J. M. (2000). The wheel of wellness counseling for wellness: A holistic model for treatment planning. Journal of Counseling and Development, 78, 251-266. https://doi.org/10.1002/j.1556-6676.2000.tb01906.x

National Institute of Allergy and Infectious Diseases (2019, September 23). Researching Ebola in Africa. https://www.niaid.nih.gov/disea ses-conditions/researching-ebola-africa

UN News (2020, May 12). Covid-19 pandemic "quickly becoming a child rights crisis". https://news.un.org/en/story/2020/05/1063822

Noble, K., Hurley, P. \& Macklin, S. (2020). COVID-19, employment stress and student vulnerability in Australia. Victoria: Victoria University/Mitchell Institute for Education and Health Policy, Victoria University. http://vuir.vu.edu.au/40603/1/COVID-19\% 20employment $\% 20$ stress\%20and\%20child\%20vulnerability.pdf

OMEP Executive Committee. (2020). OMEP Position Paper: Early Childhood Education and Care in the Time of COVID-19. International Journal of Early Childhood. https://doi.org/10.1007/ s13158-020-00273-5

Otu, A., Charles, C. H., \& Yaya, S. (2020). Mental health and psychosocial well-being during the COVID-19 pandemic: The invisible elephant in the room. International Journal of Mental Health Systems, 14, 1-5. https://doi.org/10.1186/s13033-020-00371-w

Peters, M. A., Wang, H., Ogunniran, M. O., Huang, Y., Green, B., Chunga, J. O., Quainoo, E. A., Ren, Z., Hollings, S., Mou, C., \& Khomera, S. W. (2020). China's internationalized higher education during COVID-19: Collective student autoethnography. Postdigital Science and Education, 2, 968-988. https://link.springer. com/content/pdf/10.1007/s42438-020-00128-1.pdf

Reimers, F. M., \& Schleicher, A. (2020). A framework to guide an education response to the COVID-19 pandemic of 2020. Retrieved from https://globaled.gse.harvard.edu/files/geii/files/framework_ guide_v1_002.pdf

Roy, A. (2020, 3 April). The pandemic is a portal. Financial Times. Retrieved from https://www.ft.com/content/10d8f5e8-74eb-11ea95fe-fcd274e920ca

Rundle, A. G., Park, Y., Herbstman, J. B., Kinsey, E. W., \& Wang, Y. C. (2020). COVID-19-related school closings and risk of weight gain among children. Obesity, 28(6), 1008-1009. https://doi.org/ 10.1002/oby. 22813

Schimmenti, A., Billieux, J., \& Starcevic, V. (2020). The four horsemen of fear: An integrated model of understanding fear experiences during the COVID-19 pandemic. Clinical Neuropsychiatry, 17(2), 41-45. https://doi.org/10.36131/CN20200202

Shackle, S. (2019, September 27). "The way universities are run is making us ill": Inside the student mental health crisis. The Guardian. Retrieved from: https://www.theguardian.com/society/2019/ sep/27/anxiety-mental-breakdowns-depression-uk-students?utm source $=$ pocket-newtab

Silverman, M., Sibbald, R., \& Stranges, S. (2020). Ethics of COVID19-related school closures. Canadian Journal of Public Health, 111, 462-465. https://doi.org/10.17269/s41997-020-00396-1

Sklar, J. (2020). 'Zoom fatigue' is taxing the brain. Here's why that happens. National Geographic. https://www.nationalgeographic. $\mathrm{com} /$ science/2020/04/coronavirus-zoom-fatigue-is-taxing-thebrain-here-is-why-that-happens/

Stewart, D. W., Davoren, A. K., Neumeister, J. R., Knepler, E., Grigorian, K., \& Greene, A. (2021). Graduate schools respond to COVID-19: Promising pathways to innovation and sustainability in stem education (executive summary). Chicago: NORC/University of Chicago. NORC COVID Executive Summary 2021ss.

Szente, J. (2020). Live virtual sessions with toddlers and preschoolers amid COVID-19: Implications for early childhood teacher education. Journal of Technology and Teacher Education, 28(2), 373-380. https://eric.ed.gov/?=EJ257409

The WHO-UNICEF-Lancet Commissioners. (2020). After COVID19, a future for the world's children? The Lancet, 396(10247), 298-300. https://doi.org/10.1016/S0140-6736(20)31481-1

UNESCO. (2020a). COVID-19 educational disruption and response. UNESCO. https://en.unesco.org/news/COVID-19-educationaldisruption-and-response

UNESCO. (2020b) Amidst global school closures UNESCO's Futures of Education initiative receives strong support. https://en.unesco. org/news/amidst-global-school-closures-unescosfutures-educa tion-initiative-receives-strong-support.

United Nations. (2020). Policy brief: The impact of COVID-19 on children. https://unsdg.un.org/resources/policy-brief-impact-covid19-children

Usher, K., Bhullar, N., Durkin, J., Gyamfi, N., \& Jackson, D. (2020). Family violence and COVID-19: Increased vulnerability and reduced options for support. International Journal of Mental Health Nursing, 29(4), 549-552. https://doi.org/10.1111/inm. 12735

Van Lancker, W., \& Parolin, Z. (2020). COVID-19, school closures, and child poverty: A social crisis in the making. The Lancet, 5(5), E243-E244. https://doi.org/10.1016/S2468-2667(20)30084-0

Waddoups, A. B., Yoshikawa, H., \& Strouf, K. (2019). Developmental effects of parent-child separation. Annual Review of Developmental Psychology, 1, 387-410. https://www.annualreviews.org/doi/ abs/10.1146/annurev-devpsych-121318-085142

Watermeyer, R., Crick, T., Knight, C., \& Goodall, J. (2020). COVID-19 and digital disruption in UK universities: Afflictions and affordances of emergency online migration. Higher Education. https:// doi.org/10.1007/s10734-020-00561-y

Whalen, J. (2020). Should teachers be trained in emergency remote teaching? Lessons learned from the COVID-19 pandemic. Journal of Technology and Teacher Education, 28(2), 189-199. https:// eric.ed.gov/?id=EJ1257153

Witt, A., Ordóñez, A., Martin, A., Vitiello, B., \& Fegert, J. M. (2020). Child and adolescent mental health service provision and research during the COVID-19 pandemic: Challenges, opportunities, and a call for submissions. Child and Adolescent Psychiatry and Mental Health. https://doi.org/10.1186/s13034-020-00324-8

World Health Organization. (2020). Mental health and COVID-19. https://www.who.int/teams/mental-health-and-substance-use/ COVID-19

Xafis, V. (2020). 'What is inconvenient for you is life-saving for me': How health inequities are playing out during the COVID-19 
pandemic. Asian Bioethics Review, 12, 223-234. https://pubmed. ncbi.nlm.nih.gov/32427219

Xafis, V., Schaefer, G. O., Labude, M. K., Zhu, Y., \& Hsu, L. Y. (2020). The perfect moral storm: Diverse ethical considerations in the COVID-19 pandemic. Asian Bioethics Review, 12, 65-83. https:// link.springer.com/article/10.1007/s41649-020-00125-3

Yoshikawa, H., Wuermli, A. J., Britto, P. R., Dreyer, B., Leckman, J. F., Lye, S. J., Ponguta, L. A., Richter, L. M., \& Stein, A. (2020). Effects of the global coronavirus disease-2019 pandemic on early childhood development: short-and long-term risks and mitigating program and policy actions. The Journal of Pediatrics, 223, 188193. https://doi.org/10.1016/j.jpeds.2020.05.020
Zhu, X., \& Liu, J. (2020). Education in and after COVID-19: Immediate responses and long-term visions. Postdigital Science and Education, 2(3), 695-699. https://link.springer.com/content/pdf/ 10.1007/s42438-020-00126-3.pdf

Publisher's Note Springer Nature remains neutral with regard to jurisdictional claims in published maps and institutional affiliations. 